\title{
Advanced oxidation of high concentrations of formaldehyde in aqueous solution under fluorescent and UV light
}

\author{
Fatma Deniz $^{*(\mathbb{D}}$, Mehmet Ali Mazmanci ${ }^{(\mathbb{D}}$ \\ Department of Environmental Engineering, Mersin University, Mersin, Turkey
}

\begin{abstract}
Background: Formaldehyde (FA) is a carcinogen compound, which is soluble in water. FA can be removed from aqueous solution using advanced oxidation methods.

Methods: In this study, the oxidation of FA was studied under fluorescent and UV light. Hydrogen peroxide $\left(\mathrm{H}_{2} \mathrm{O}_{2}\right)$ was used as an oxidant. The $\mathrm{pH}$ value and $\mathrm{H}_{2} \mathrm{O}_{2}$ amount of samples were optimized. The chemical oxygen demand (COD), FA concentration, and $\mathrm{H}_{2} \mathrm{O}_{2}$ consumption were followed. Results: It was observed that the $\mathrm{pH}$ value of the sample was more significant under fluorescent light than UV light at oxidation of FA. The highest COD removal and $\mathrm{H}_{2} \mathrm{O}_{2}$ reduction were 18.57 and $30.90 \%$, respectively, at $\mathrm{pH} 12.00$, with a $1: 1$ ratio of $\mathrm{FA}: \mathrm{H}_{2} \mathrm{O}_{2}$ under fluorescent light. $86.41 \% \mathrm{FA}$ and $62.12 \%$ COD removal were achieved at $\mathrm{pH} 7.00$, with a $1: 2$ ratio of $\mathrm{FA}: \mathrm{H}_{2} \mathrm{O}_{2}$, under UV light. It was observed that $\mathrm{H}_{2} \mathrm{O}_{2}$ was consumed at all $\mathrm{pH}$ values under UV light. On the other hand, under fluorescent light, the concentration of $\mathrm{H}_{2} \mathrm{O}_{2}$ decreased only at $\mathrm{pH}$ 12. In control samples containing only $\mathrm{H}_{2} \mathrm{O}_{2}$, the $\mathrm{H}_{2} \mathrm{O}_{2}$ reduction was $92.09 \%$ at $\mathrm{pH} 11.91$, while it was 2-6\% at other $\mathrm{pH}$ levels under fluorescent light. The $\mathrm{H}_{2} \mathrm{O}_{2}$ reduction changed between 33 and $44 \%$ at different $\mathrm{pH}$ values under UV light. The oxidation of FA was found to be suitable for the pseudo-first-order kinetic model and Langmuir isotherm model. Conclusion: The most effective oxidation was obtained at the original $\mathrm{pH}$ value (7.00) and 1:2 ratio of FA: $\mathrm{H}_{2} \mathrm{O}_{2}$ under UV light.

Keywords: Water treatment, Formaldehyde, UV light, Hydrogen peroxide

Citation: Deniz F, Mazmanc1 MA. Advanced oxidation of high concentrations of formaldehyde in aqueous solution under fluorescent and UV light. Environmental Health Engineering and Management Journal 2021; 8(4): 267-276. doi: 10.34172/EHEM.2021.30.
\end{abstract}

\author{
Article History: \\ Received: 21 April 2021 \\ Accepted: 15 June 2021 \\ ePublished: 15 November 2021
}

\section{Introduction}

Formaldehyde (FA) is a colorless, flammable gas, which is soluble in water, acetone, ethanol, benzene, diethyl ether, and chloroform. It can also be decomposed when exposed to light (1). It is dissolved in water at a rate of $40 \%$, and its aqueous solution is called formalin $(1,2)$. FA is used in plastic and resin production. It is also used in many medicines and cosmetic products, veterinary drugs, fungicides, embalming, and textile products (2-6). The aqueous solution containing FA occurs after producing these products and being discharged into the wastewater system from facilities $(5,7,8)$. FA has been classified as a carcinogen by the International Agency for Research on Cancer (IARC) $(3,9)$. Therefore, water containing FA must be treated. Biological treatment of wastewater containing FA in high concentrations is difficult due to its toxic effect on living organisms $(3,10)$. Advanced oxidation processes (AOPs) are an alternative treatment method for organic compounds that are difficult to decompose by biological methods $(11,12)$. In previous studies, researchers have applied various AOP methods such as electro-oxidation
(13), photocatalytic degradation with nano- $\mathrm{TiO}_{2}$ (14), composite $\mathrm{Ag} / \mathrm{TiO}_{2}(15), \mathrm{UV} / \mathrm{H}_{2} \mathrm{O}_{2}$, Fenton and photoFenton (3,16), UVC/ $\mathrm{S}_{2} \mathrm{O}_{8}{ }^{-2}(17)$, and photocatalytic degradation by $\mathrm{Fe} / \mathrm{TiO}_{2}(18)$, for FA oxidation. AOPs are a type of oxidation performed using hydroxyl radicals $\left(\mathrm{OH}^{*}\right)$ $(4,19)$. It is known that the organics photodegradation is affected by $\mathrm{OH}$ radicals (20). Hydroxyl radicals react with any organic substances around thanks to their unpaired electrons, and they transform organic substances into products such as $\mathrm{CO}_{2}$ and $\mathrm{H}_{2} \mathrm{O}$ under suitable conditions $(4,19)$.

AOPs are based on highly reactive radicals' on-site production to decompose organic pollutants in water. These processes include homogeneous and heterogeneous chemical and photochemical processes, such as UV photolysis, mostly performed using chemical oxidants such as $\mathrm{O}_{3}, \mathrm{H}_{2} \mathrm{O}_{2}$ or catalysts like $\mathrm{TiO}_{2}$, electrochemical oxidation, Fenton processes, supercritical water, and wet air oxidation, sonochemical processes, and various combinations of these methods $(4,21)$.

UV-based AOPs are methods based on the use of UV 
light with or without different oxidants such as $\mathrm{O}_{3}, \mathrm{H}_{2} \mathrm{O}_{2}$, $\mathrm{TiO}_{2}$, and $\mathrm{H}_{2} \mathrm{O}_{2} / \mathrm{Fe}^{+2}$ (Photo-Fenton reaction) (1,2). However, the disadvantage of these methods is their cost. Therefore, the cost can be reduced by optimizing parameters such as $\mathrm{pH}$, oxidant dose, and UV exposure time (4).

Using AOPs with UV has become an alternative for degradation of organic pollutants that cannot be removed by conventional methods. Among the UV-based AOPs, $\mathrm{UV} / \mathrm{H}_{2} \mathrm{O}_{2}$ is a promising technology (22). $\mathrm{H}_{2} \mathrm{O}_{2}$ is one of the strong oxidants that reacts with UV light at wavelengths below $290 \mathrm{~nm}$ and forms hydroxyl radicals. The reaction equation of $\mathrm{H}_{2} \mathrm{O}_{2}$ with UV light is given in Eq. (1) (23).

$$
\mathrm{H}_{2} \mathrm{O}_{2}+h v \rightarrow 2 \mathrm{OH}
$$

The reaction efficiency varies according to $\mathrm{pH}$ level of the environment, time and intensity of UV exposure, and $\mathrm{H}_{2} \mathrm{O}_{2}$ concentration. $\mathrm{H}_{2} \mathrm{O}_{2}$ gives different reactions at different $\mathrm{pH}$ levels. The rate of degradation increases at basic $\mathrm{pH}$ under UV light (23).

This study aimed to observe the change of FA and $\mathrm{H}_{2} \mathrm{O}_{2}$ in an aqueous solution under fluorescent and UV light in the presence of $\mathrm{H}_{2} \mathrm{O}_{2}$ and to determine the most effective conditions for FA removal.

\section{Materials and Methods}

Fluorescence $/ \mathrm{H}_{2} \mathrm{O}_{2}$ and $\mathrm{UV} / \mathrm{H}_{2} \mathrm{O}_{2}$ oxidation experiments This study is consisted of $\mathrm{pH}$ optimization and $\mathrm{FA}: \mathrm{H}_{2} \mathrm{O}_{2}$ ratio optimization under fluorescent and UV light with $\mathrm{H}_{2} \mathrm{O}_{2}$, separately.

The synthetic water samples were prepared using $37 \%$ FA solution. The $\mathrm{pH}$ values of synthetic water samples were adjusted as approximately 3.00, 6.00, 9.00, and 12.00 at the $\mathrm{pH}$ optimization. Also, the original $\mathrm{pH}$ of the sample ( 7.00) was studied at UV experiments. The $\mathrm{pH}$ of the samples was adjusted using $\mathrm{H}_{2} \mathrm{SO}_{4}$ and $\mathrm{NaOH}$ solutions. The final FA concentration of samples was 1000 $\mathrm{mg} / \mathrm{L}$. The samples were placed in a magnetic stirrer under fluorescent and UV light, separately. $\mathrm{H}_{2} \mathrm{O}_{2}$ was added to each sample to reach the final $\mathrm{H}_{2} \mathrm{O}_{2}$ concentration of $1000 \mathrm{mg} / \mathrm{L}$ after adjusting the $\mathrm{pH}$ value. The $\mathrm{FA}: \mathrm{H}_{2} \mathrm{O}_{2}$ concentration ratio was 1:1. The samples containing only FA $(1000 \mathrm{mg} / \mathrm{L})$ and only $\mathrm{H}_{2} \mathrm{O}_{2}(500 \mathrm{mg} / \mathrm{L})$ were used as the control groups.

The $\mathrm{pH}$ of samples was adjusted as the optimum $\mathrm{pH}$ at the FA: $\mathrm{H}_{2} \mathrm{O}_{2}$ ratio optimization. The final FA concentration of samples was $1000 \mathrm{mg} / \mathrm{L} . \mathrm{H}_{2} \mathrm{O}_{2}$ was added to each sample so that the samples' final $\mathrm{H}_{2} \mathrm{O}_{2}$ concentrations were 1000,2000 , and $3000 \mathrm{mg} / \mathrm{L}$, respectively, and the ratio of FA: $\mathrm{H}_{2} \mathrm{O}_{2}$ were $1: 1,1: 2$, and 1:3, respectively.

Three different FA concentrations (500, 1000, and 1500 $\mathrm{mg} / \mathrm{L}$ ) were studied to examine the initial concentration of FA.

A UV-C lamp (8 W, $254 \mathrm{~nm})$ was used for $\mathrm{UV} / \mathrm{H}_{2} \mathrm{O}_{2}$ oxidation. The distance between the light source and the sample was $2 \mathrm{~cm}$. The surrounding of the system was arranged to keep samples and a light source inside. The samples were collected at specific time intervals for chemical oxygen demand (COD), FA, $\mathrm{H}_{2} \mathrm{O}_{2}$ analysis, and $\mathrm{pH}$ measuring. All experiments were performed at room temperature.

\section{Analytical methods}

The COD analysis was performed according to Standard Methods 5220-D (24), and $\mathrm{H}_{2} \mathrm{O}_{2}$ analysis was performed according to method $\mathrm{I}^{-3}$ (25). Hach Lange LCK 425 kits were used for FA analysis. Colorimetric measurements were made with the Hach Lange DR3900 UV-visible spectrophotometer.

The removal efficiency (\%) was calculated as follows:

Removal efficiency, $\%=\frac{[\text { input }]-[\text { output }]}{[\text { input }]} \times 100$

Langmuir and Freundlich isotherms were calculated to compare the adsorption isotherms.

Pseudo-first-order, pseudo-second-order, and intraparticle diffusion kinetic models were applied to compare adsorption kinetics.

Results

pH optimization for $\mathrm{FA}$ removal with $\mathrm{H}_{2} \mathrm{O}_{2}$ in water samples

It was aimed to investigate the effect of different $\mathrm{pH}$ levels on the oxidation of FA $(1000 \mathrm{mg} / \mathrm{L})$ with $\mathrm{H}_{2} \mathrm{O}_{2}(1000$ $\mathrm{mg} / \mathrm{L}$ ) under fluorescent and UV light. For fluorescent light experiments, $\mathrm{pH}$ values were adjusted as 3.00, 6.02, 9.10, and 12.00. The COD removal at $\mathrm{pH} 3.00,6.02$, and 9.10 varied between 1 and $12 \%$. At $\mathrm{pH} 12.00$, the COD decrease in the first 10 minutes was $18.57 \%$ (Figure 1a). The highest COD removal was obtained at $\mathrm{pH} 12.00$ in the presence of $\mathrm{H}_{2} \mathrm{O}_{2}$. For UV light experiments, $\mathrm{pH}$ values were arranged as 3.04, 5.92, 7.02 (original pH), 9.10, 12.24, and COD removal was obtained as 30, 34, 43, 43 , and $44 \%$ in samples, respectively (Figure 1b). During the experiment, the change in the amount of $\mathrm{H}_{2} \mathrm{O}_{2}$ was followed under fluorescent light. The amount of $\mathrm{H}_{2} \mathrm{O}_{2}$ was not changed at $\mathrm{pH} 3.00,6.02$, and 9.10. However, at $\mathrm{pH} 12.00$, a $20 \%$ reduction was observed in the first 10 minutes. $\mathrm{H}_{2} \mathrm{O}_{2}$ reduction reached $30.90 \%$ after 300 minutes (Figure 2a). Under UV light, it was observed that almost all of $\mathrm{H}_{2} \mathrm{O}_{2}(1000 \mathrm{mg} / \mathrm{L})$ was consumed at each $\mathrm{pH}$ level (Figure 2b).

The changes in $\mathrm{pH}$ of samples were followed, and each sample's $\mathrm{pH}$ decreased at the end of the experiment at both light sources (Tables 1 and 2).

Sample containing only FA (1000 mg/L) and only $\mathrm{H}_{2} \mathrm{O}_{2}$ $(500 \mathrm{mg} / \mathrm{L})$ were studied as the control groups. In samples containing only FA, the COD values were followed. Under fluorescent light, the COD values remained the same. The 

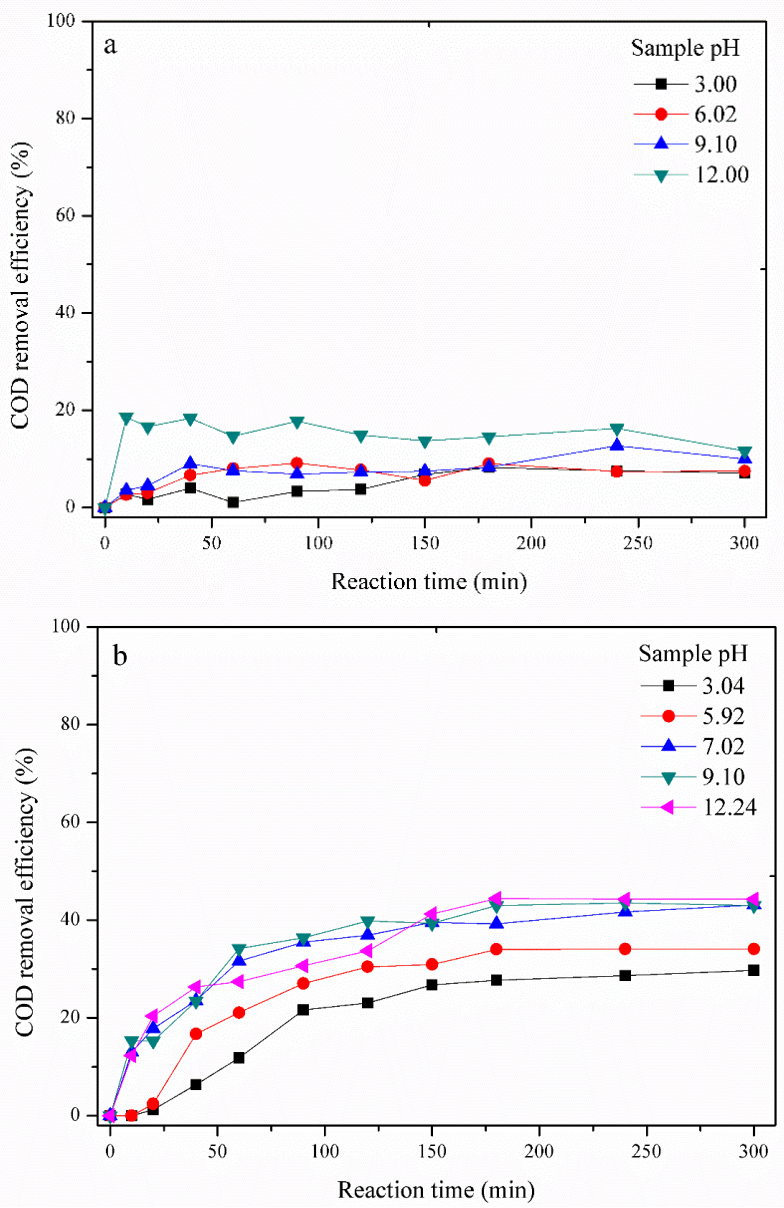

Figure 1. COD removal (\%) in samples containing $\mathrm{FA}$ and $\mathrm{H}_{2} \mathrm{O}_{2}(1: 1)$ at different $\mathrm{pH}$ levels, under (a) fluorescent and (b) UV light.

highest COD removal (6\%) was obtained under UV light.

Optimization of FA: $\mathrm{H}_{2} \mathrm{O}_{2}$ ratio in $\mathrm{FA}$ removal with $\mathrm{H}_{2} \mathrm{O}_{2}$ in water samples

The effect of different concentrations of $\mathrm{H}_{2} \mathrm{O}_{2}(1000,2000$, and $3000 \mathrm{mg} / \mathrm{L}$ ) was observed for two light sources. The FA: $\mathrm{H}_{2} \mathrm{O}_{2}$ concentration ratio was adjusted as $1: 1,1: 2$, and 1:3. It was aimed to observe the effect of increasing $\mathrm{H}_{2} \mathrm{O}_{2}$ amount on the COD removal and to find the optimum FA: $\mathrm{H}_{2} \mathrm{O}_{2}$ rate. This experiment was performed at $\mathrm{pH}$ 12.00 under fluorescent light and at the sample's original $\mathrm{pH}(\sim 7.00)$ under UV light. The COD removal decreased as the $\mathrm{H}_{2} \mathrm{O}_{2}$ concentration of the samples increased under fluorescent light. The highest COD removals for FA: $\mathrm{H}_{2} \mathrm{O}_{2}$ ratio of $1: 1,1: 2$, and 1:3 were calculated to be $18.57,9.60$, and $10.19 \%$, respectively (Figure $3 a$ ). The COD removal efficiencies at the ratio of $1: 1,1: 2$, and $1: 3\left(\mathrm{FA}: \mathrm{H}_{2} \mathrm{O}_{2}\right)$ were found to be $43.13,62.16$, and $53.78 \%$ under UV light, respectively (Figure $3 \mathrm{~b}$ ). The changes in $\mathrm{H}_{2} \mathrm{O}_{2}$ amount were followed. Under fluorescent light, $\mathrm{H}_{2} \mathrm{O}_{2}$ concentration decreased $20.39,3.59$, and $0.67 \%$ for samples with a ratio of $1: 1,1: 2$, and 1:3, respectively, at the 10th minute. At the end of the reaction time (300 minutes), the decrease rates in $\mathrm{H}_{2} \mathrm{O}_{2}$ were $30.90,13.79$, and $9.28 \%$ for the $1: 1,1: 2$, and 1:3 ratios, respectively (Figure $4 \mathrm{a}$ ). Under UV light, the decrease in $\mathrm{H}_{2} \mathrm{O}_{2}$ concentrations were 93.69, 95.94, and $59.47 \%$ for the ratio of $1: 1,1: 2$, and $1: 3$, respectively (Figure 4b).

It was observed that under fluorescent light, the $\mathrm{pH}$ decreased at the end of the experiment and the highest decrease occurred at 1:1 FA: $\mathrm{H}_{2} \mathrm{O}_{2}$ sample (Table 3). Under UV light, the initial $\mathrm{pH}$ (7.02) in all proportions studied was measured at 2.60 levels after 300 minutes. The sample's $\mathrm{pH}$ change at the ratio of 1:2 was followed during the experiment. The $\mathrm{pH}$ value was measured as 3.88 in the 10th minute (Figure 5). During the experiment at the optimum conditions, the FA concentration decreased from 1060 to $144 \mathrm{mg} / \mathrm{L}$, and the COD value decreased from 1380.92 to $522.58 \mathrm{mg} / \mathrm{L}$.

\section{The initial concentration of FA}

Initial FA concentrations (500, 1000 and $1500 \mathrm{mg} / \mathrm{L})$ were studied to calculate the kinetic and isotherm parameters containing $\mathrm{H}_{2} \mathrm{O}_{2}(1000 \mathrm{mg} / \mathrm{L})$ under UV light. The results showed that COD removal efficiencies were 66.04, 34.71, and 10.85 for FA concentrations of 500, 1000, and 1500 $\mathrm{mg} / \mathrm{L}$, respectively. $\mathrm{H}_{2} \mathrm{O}_{2}$ was totally consumed at all tested FA concentrations.
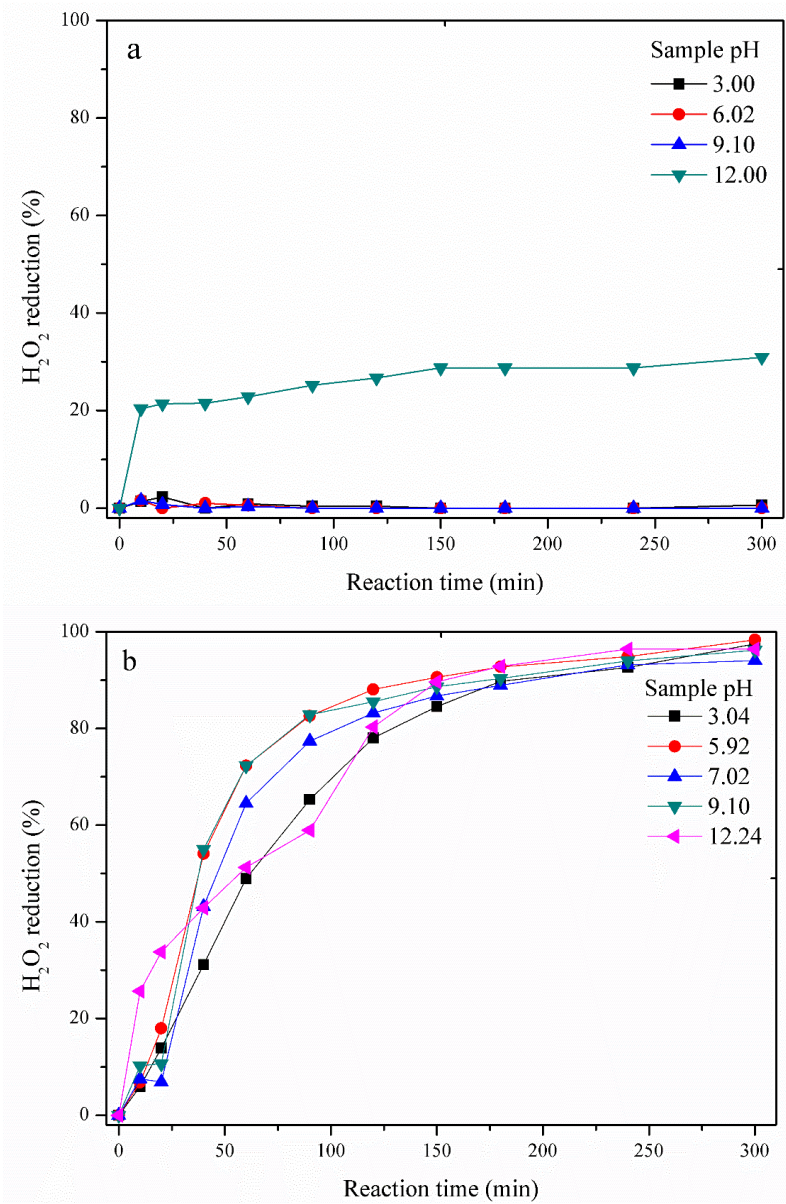

Figure 2. $\mathrm{H}_{2} \mathrm{O}_{2}$ concentration change (\%) in samples containing FA and $\mathrm{H}_{2} \mathrm{O}_{2}$ (1:1) at different $\mathrm{pH}$ levels under (a) fluorescent and (b) UV light. 
Table 1. Initial and final $\mathrm{pH}$ values of samples containing $\mathrm{FA}$ and $\mathrm{H}_{2} \mathrm{O}_{2}(1: 1)$ under fluorescent light

\begin{tabular}{lllll}
\hline Initial pH & 3.00 & 6.02 & 9.10 & 12.00 \\
\hline Final pH & 2.91 & 3.60 & 4.00 & 7.53 \\
\hline
\end{tabular}

Table 2. Initial and final $\mathrm{pH}$ values of samples containing $\mathrm{FA}$ and $\mathrm{H}_{2} \mathrm{O}_{2}$ at a ratio of $1: 1$ under UV light

\begin{tabular}{llllll}
\hline Initial pH & 3.04 & 5.92 & 7.02 & 9.10 & 12.24 \\
\hline Final pH & 2.61 & 2.73 & 2.64 & 2.70 & 6.62 \\
\hline
\end{tabular}

Table 3. Initial and final $\mathrm{pH}$ values of samples containing different ratios of $\mathrm{FA}: \mathrm{H}_{2} \mathrm{O}_{2}$ under fluorescent light

\begin{tabular}{lccc}
\hline FA: $\mathrm{H}_{2} \mathrm{O}_{2}$ & $1: 1$ & $1: 2$ & $1: 3$ \\
\hline Initial pH & 12.00 & 11.99 & 11.99 \\
\hline Final pH & 7.53 & 8.14 & 8.45 \\
\hline
\end{tabular}

\section{Kinetic and isotherm studies}

According to the results, oxidation of FA with $\mathrm{UV} / \mathrm{H}_{2} \mathrm{O}_{2}$ process was performed with pseudo-first-order kinetic and Langmuir isotherm model.

\section{Discussion}

pH optimization for formaldehyde (FA) removal with $\mathrm{H}_{2} \mathrm{O}_{2}$ in water samples

The COD removal at $\mathrm{pH} 3.00,6.02$, and 9.10 varied between 1 and 12\%. At pH 12.00, the COD decrease in the first 10 minutes was $18.57 \%$ (Figure 1a). The highest COD removal was obtained at $\mathrm{pH} 12.00$ in the presence of $\mathrm{H}_{2} \mathrm{O}_{2}$ under fluorescent light. A similar study was studied by Guimarães et al (3). They reported that there was a 99.3\% decrease in the concentration of FA with $\mathrm{H}_{2} \mathrm{O}_{2}$. However, there was no change in the amount of dissolved organic carbon. This may be due to conversion of FA into trioxymethylene or formic acid (3). Surpateanu et al have studied three different $\mathrm{pH}$ values $(6.80,9.79$, and 11.81) on cyanide oxidation with $\mathrm{H}_{2} \mathrm{O}_{2}$. They reported that oxidation of cyanide was more effective at basic $\mathrm{pH}$. Also, they reported that after the 50th minute of the experiment, the oxidation rate increased in the sample at a neutral $\mathrm{pH}$ (26).

For UV light experiments, $\mathrm{pH}$ values were arranged as 3.04, 5.92, 7.02 (original pH), 9.10, 12.24, and COD removal was obtained as $30,34,43,43$, and $44 \%$ in samples, respectively (Figure $1 \mathrm{~b}$ ). The COD removal increased with increasing $\mathrm{pH}$ from 3.04 to 12.24 . A similar result has been reported by Abbaszadeh Haddad et al (27). At $\mathrm{pH} 7.02,9.10$, and 12.24, the COD removal efficiency was close to each other. The results have shown that oxidation occurred. The COD values decreased at each $\mathrm{pH}$ level; however, the higher removal was obtained in neutral and basic conditions (Figure 1b). The low degradation in acidic $\mathrm{pH}$ can be attributed to the loss of $\mathrm{OH}$ ions since proton prevents the formation of $\mathrm{OH}$ radicals (11). Researchers have studied the $\mathrm{UV} / \mathrm{H}_{2} \mathrm{O}_{2}$ process at different $\mathrm{pH}$ levels $(3,16,28)$.

During the experiment, the change in the amount of $\mathrm{H}_{2} \mathrm{O}_{2}$ was followed under fluorescent light. The amount of $\mathrm{H}_{2} \mathrm{O}_{2}$ was not changed at $\mathrm{pH} 3.00,6.02$, and 9.10. However, at $\mathrm{pH} 12.00$, a $20 \%$ reduction was observed in the first 10 minutes. $\mathrm{H}_{2} \mathrm{O}_{2}$ reduction reached $30.90 \%$ after 300 minutes (Figure 2a). It has been reported that sodium formate (HCOONa), water, and $\mathrm{H}_{2}$ compounds are formed due to $\mathrm{H}_{2} \mathrm{O}_{2}$ and FA's reaction with $\mathrm{NaOH}$ in basic conditions. The reaction of $\mathrm{H}_{2} \mathrm{O}_{2}$ and $\mathrm{FA}$ at basic $\mathrm{pH}$ is explained as follows (29):

$\mathrm{H}_{2} \mathrm{O}_{2}+\mathrm{HCHO} \rightarrow \mathrm{HOCH}_{2} \mathrm{OOH}$

$\mathrm{HOCH}_{2} \mathrm{OOH}+\mathrm{HCHO} \rightarrow \mathrm{HOCH}_{2} \mathrm{OOCH}_{2} \mathrm{OH}$

$\mathrm{HOCH}_{2} \mathrm{OOCH}_{2} \mathrm{OH}+2 \mathrm{NaOH} \rightarrow \mathrm{H}_{2}+2 \mathrm{HCOONa}+2 \mathrm{H}_{2} \mathrm{O}$

At the 10th minute of the experiment, air bubbles were observed at $\mathrm{pH} 12.00$. It has been reported in the literature that air bubbles occur in the presence of $\mathrm{H}_{2} \mathrm{O}_{2}, \mathrm{FA}$, and $\mathrm{NaOH}$. The air bubbles were caused by $\mathrm{H}_{2}$ gas given in
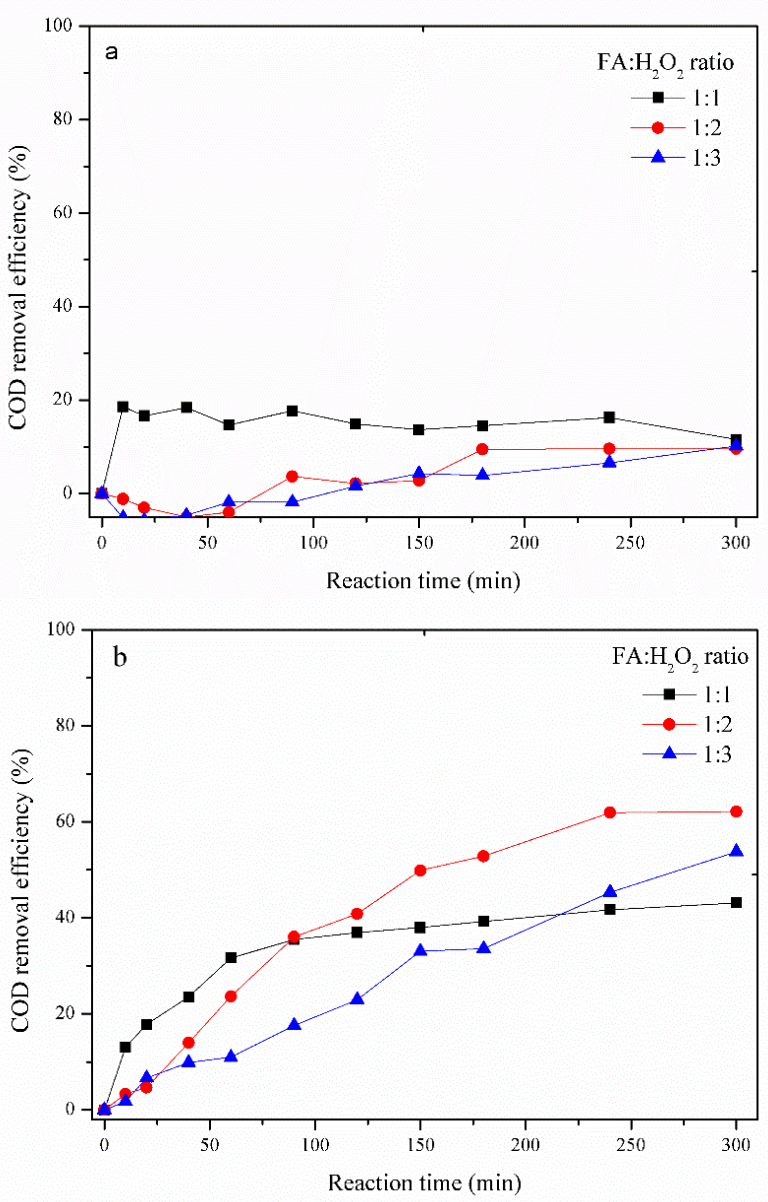

Figure 3. COD removal (\%) in samples containing $\mathrm{FA}: \mathrm{H}_{2} \mathrm{O}_{2}$ at the ratio of $1: 1,1: 2$, and 1:3 under (a) fluorescent and (b) UV light. 

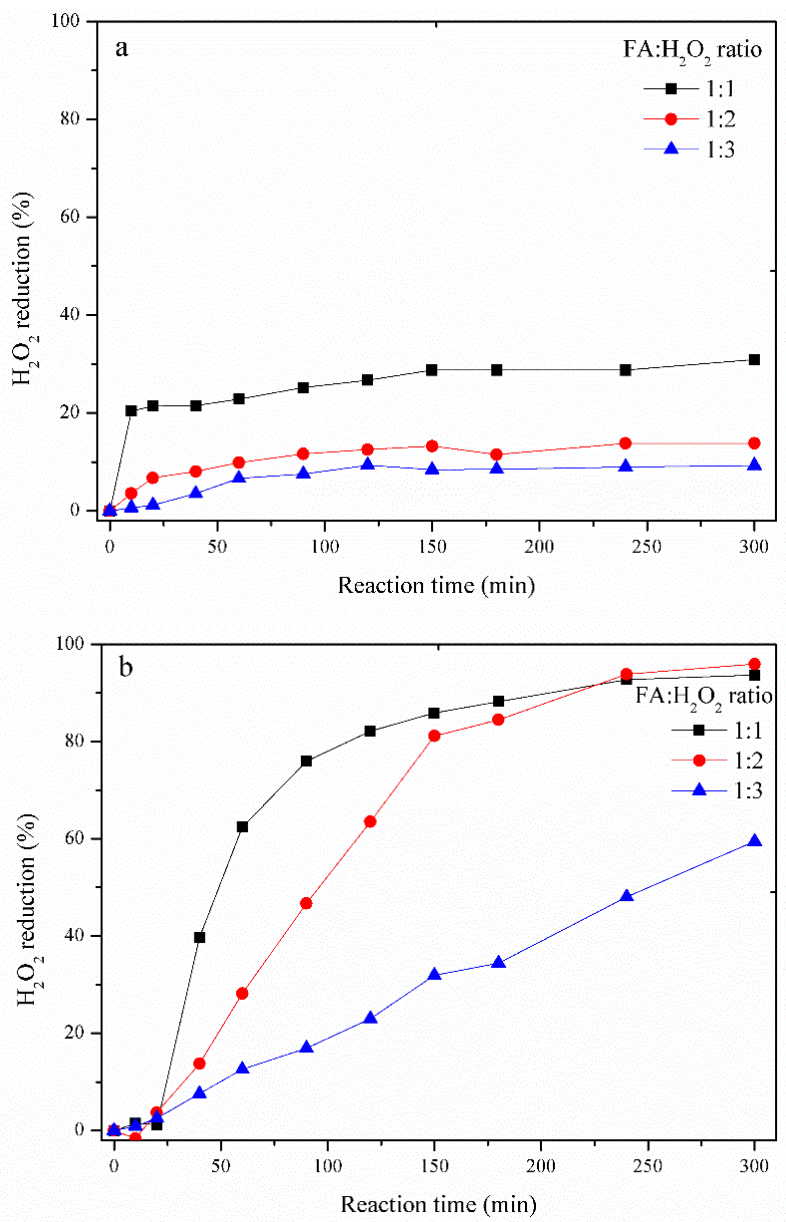

Figure 4. Change in $\mathrm{H}_{2} \mathrm{O}_{2}$ concentration (\%) in samples containing $1: 1,1: 2$, and 1:3 FA: $\mathrm{H}_{2} \mathrm{O}_{2}$ ratio under (a) fluorescent and (b) UV light.

Eq. (5) (29).

$\mathrm{H}_{2} \mathrm{O}_{2}$ is one of the strong oxidants that reacts with UV light at wavelengths below $290 \mathrm{~nm}$. In the $\mathrm{UV} / \mathrm{H}_{2} \mathrm{O}_{2}$ process, UV light catalyzes the decomposition of $\mathrm{H}_{2} \mathrm{O}_{2}$ into hydroxyl radicals through chain reactions. These radicals are strong oxidants that react with organic compounds in water (23).

$\mathrm{H}_{2} \mathrm{O}_{2}+\mathrm{hv} \rightarrow 2 \mathrm{OH}^{\cdot}$

When the organic pollutant reacts with $\mathrm{OH}$ radicals, $\mathrm{CO}_{2}, \mathrm{H}_{2} \mathrm{O}$, etc. (Equation 7) (30,31), it provides the COD removal. In this study, FA was transformed into $\mathrm{CO}_{2}, \mathrm{H}_{2} \mathrm{O}$, and intermediates.

Organic pollutant $+\mathrm{OH}^{\cdot} \rightarrow \mathrm{CO}_{2}+\mathrm{H}_{2} \mathrm{O}+$ etc.

These reactions' efficiencies depend on the $\mathrm{pH}$ level of the environment, duration of UV exposure, intensity of UV exposure, and $\mathrm{H}_{2} \mathrm{O}_{2}$ concentration (23). In this study, $\mathrm{OH}$ radicals formed by the effect of UV light carried out FA oxidation. As a result, up to $44 \%$ of COD removal was achieved.
Under UV light, it was observed that almost all of $\mathrm{H}_{2} \mathrm{O}_{2}$ $(1000 \mathrm{mg} / \mathrm{L})$ was consumed at each $\mathrm{pH}$ level (Figure 2b). The findings show that different $\mathrm{pH}$ levels did not affect the change of $\mathrm{H}_{2} \mathrm{O}_{2}$, and $\mathrm{H}_{2} \mathrm{O}_{2}$ reduction occurred at the same rate at each $\mathrm{pH}$ level. However, the fastest $\mathrm{H}_{2} \mathrm{O}_{2}$ consumption was at $\mathrm{pH} 12.00$ in the first minutes of the experiment, as in the fluorescent light experiments. Under fluorescent light, the $\mathrm{pH}$ levels of samples affected the decomposition of $\mathrm{H}_{2} \mathrm{O}_{2}$. The most effective $\mathrm{pH}$ level was 12.00 .

Under UV light, COD removal and $\mathrm{H}_{2} \mathrm{O}_{2}$ consumption increased until the 180th minute, and then, remained approximately the same. At 180th minute, at $\mathrm{pH} 3.04,5.92$, 7.02 (original $\mathrm{pH}$ ), 9.10 and 12.24 , COD removal was 28, $34,39,43$, and $44 \% ; \mathrm{H}_{2} \mathrm{O}_{2}$ consumption was 90, 93, 89, 90 , and $93 \%$, respectively (Figure $1 \mathrm{~b}$ and $2 \mathrm{~b}$ ). The results show that since the $\mathrm{H}_{2} \mathrm{O}_{2}$ concentration decreased to $10 \%$, the COD removal slowed down. Therefore, if the amount of $\mathrm{H}_{2} \mathrm{O}_{2}$ increases, COD removal will increase.

The $\mathrm{pH}$ change of samples was followed, and each sample's $\mathrm{pH}$ decreased at the end of the experiment at both light sources (Tables 1 and 2). The decrease in $\mathrm{pH}$ values was explained by converting FA to formic acid in the medium (3). Under UV light, the $\mathrm{pH}$ values dropped more than that under fluorescent light. Similar results were reported in previous studies $(3,27,32)$.

In the control samples containing only FA $(1000 \mathrm{mg} / \mathrm{L})$, the COD value was followed. Under fluorescent light, the COD values remained the same. The highest COD removal (6\%) was obtained under UV light.

$\mathrm{H}_{2} \mathrm{O}_{2}$ change was followed in the control samples containing only $\mathrm{H}_{2} \mathrm{O}_{2}(500 \mathrm{mg} / \mathrm{L})$. Under fluorescent light, $\mathrm{H}_{2} \mathrm{O}_{2}$ concentration decreased $63.62 \%$ in the 5 th minute and $92.09 \%$ at the end of 120 minutes at $\mathrm{pH}$ 11.91, but limited decomposition was found at other $\mathrm{pH}$ levels (2-6\%). The findings showed that $\mathrm{H}_{2} \mathrm{O}_{2}$ was decomposed rapidly in basic conditions. A similar result

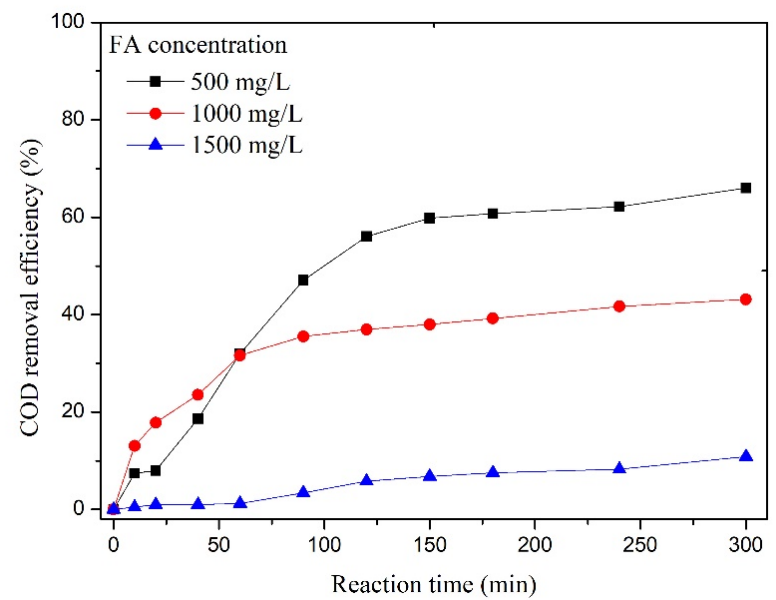

Figure 5. COD removal (\%) in samples containing 500, 1000, and 1500 $\mathrm{mg} / \mathrm{L} \mathrm{FA}$ and $1000 \mathrm{mg} / \mathrm{L} \mathrm{H}_{2} \mathrm{O}_{2}$ under UV light. 
was reported by Yazıcı and Deveci (33). Under UV light, $\mathrm{H}_{2} \mathrm{O}_{2}$ concentration decreased $42,39,33$, and $44 \%$ at $\mathrm{pH}$ $3.04,6.04,9.00$, and 12.35 , respectively. $\mathrm{H}_{2} \mathrm{O}_{2}$ decreased $33-44 \%$ under UV light in samples with $\mathrm{pH}$ values below 12.00 under the contrary fluorescent light. The results show that $\mathrm{H}_{2} \mathrm{O}_{2}$ can be decomposed under UV light at all $\mathrm{pH}$. However, $\mathrm{pH}$ is a significant parameter for $\mathrm{H}_{2} \mathrm{O}_{2}$ and FA's reactions under fluorescent light.

Optimization of $\mathrm{FA}: \mathrm{H}_{2} \mathrm{O}_{2}$ ratio in FA removal with $\mathrm{H}_{2} \mathrm{O}_{2}$ in water samples

The results obtained under UV light in $\mathrm{pH}$ optimization showed that COD removal can increase by adding $\mathrm{H}_{2} \mathrm{O}_{2}$. So, the effect of different concentrations of $\mathrm{H}_{2} \mathrm{O}_{2}(1000$, 2000 , and $3000 \mathrm{mg} / \mathrm{L}$ ) was observed for two light sources. The FA: $\mathrm{H}_{2} \mathrm{O}_{2}$ concentration ratio was adjusted as 1:1, 1:2, and 1:3. It was aimed to observe the effect of increasing $\mathrm{H}_{2} \mathrm{O}_{2}$ amount on the COD removal and to find the optimum FA: $\mathrm{H}_{2} \mathrm{O}_{2}$ rate. This experiment was performed at $\mathrm{pH} 12.00$ under fluorescent light and at the sample's original $\mathrm{pH}(\sim 7.00)$ under UV light.

The COD removal decreased as the $\mathrm{H}_{2} \mathrm{O}_{2}$ concentration of the samples increased under fluorescent light. The highest COD removals for FA: $\mathrm{H}_{2} \mathrm{O}_{2}$ ratio of $1: 1,1: 2$, and $1: 3$ were calculated as $18.57,9.60$, and $10.19 \%$, respectively (Figure 3a). But, there are opposite results obtained for different contaminants (26).

The COD removal efficiencies at the ratio of $1: 1,1: 2$, and 1:3 (FA: $\mathrm{H}_{2} \mathrm{O}_{2}$ ) were found to be $43.13,62.16$, and $53.78 \%$ under UV light, respectively (Figure $3 \mathrm{~b}$ ). COD removal increased when the $\mathrm{H}_{2} \mathrm{O}_{2}$ concentration was increased from 1000 to $2000 \mathrm{mg} / \mathrm{L}$. However, when it was increased to $3000 \mathrm{mg} / \mathrm{L}$, the COD removal decreased. This situation is attributed to the scavenging effect of excess $\mathrm{H}_{2} \mathrm{O}_{2}$ in the sample. The scavenging effect is realized by the reaction of the excess amount of $\mathrm{H}_{2} \mathrm{O}_{2}$ with the $\mathrm{OH}$ - radicals. Thus, $\mathrm{HO}_{2}$. radicals are formed (Equation 8). The $\mathrm{HO}_{2} \cdot$ radicals also react with the $\mathrm{OH}$. radicals (Equation 8 ). Therefore, $\mathrm{OH} \cdot$ radicals decrease (34).

$$
\begin{aligned}
& \mathrm{H}_{2} \mathrm{O}_{2}+\cdot \mathrm{OH} \rightarrow \mathrm{H}_{2} \mathrm{O}+\mathrm{HO}_{2} \cdot \\
& \mathrm{HO}_{2} \cdot+\cdot \mathrm{OH} \rightarrow \mathrm{H}_{2} \mathrm{O}+\mathrm{O}_{2}
\end{aligned}
$$

In a similar study, Kajitvichyanukul et al reported that they achieved $34.88 \%, 58.42 \%$, and $78.80 \%$ removal in samples containing $1: 0.5,1: 1$, and $1: 2 \mathrm{FA}: \mathrm{H}_{2} \mathrm{O}_{2}$, respectively, under UV light (16). Guimarães et al used a similar ratio and reported that $100 \% \mathrm{FA}$ and $99 \%$ dissolved organic carbon removal were obtained (3). Giri et al also investigated the removal of pharmaceutical compounds by $\mathrm{UV} / \mathrm{H}_{2} \mathrm{O}_{2}$. They have reported that as $\mathrm{H}_{2} \mathrm{O}_{2}$ concentration increased, the removal efficiency decreased for some pharmaceutical compounds (Fenoprofen and Clofibric acid). But, as $\mathrm{H}_{2} \mathrm{O}_{2}$ concentration increased for many compounds, the removal efficiency increased (35).

The change in $\mathrm{H}_{2} \mathrm{O}_{2}$ amount was followed. Under fluorescent light, $\mathrm{H}_{2} \mathrm{O}_{2}$ concentration decreased $20.39 \%$, $3.59 \%$, and $0.67 \%$ for samples with a ratio of $1: 1,1: 2$, and $1: 3$, respectively, in the 10th minute. At the end of the reaction time (300 minutes), the decrease in $\mathrm{H}_{2} \mathrm{O}_{2}$ were 30.90\% (309 mg/L), 13.79 (275.8 mg/L), and 9.28 (278.4 $\mathrm{mg} / \mathrm{L}$ ) for the 1:1, 1:2, and 1:3 ratio, respectively (Figure $4 \mathrm{a}$ ). The most effective ratio for $\mathrm{H}_{2} \mathrm{O}_{2}$ decomposition was $1: 1$. COD removal also supports this situation. It was seen that excess $\mathrm{H}_{2} \mathrm{O}_{2}$ amount could not increase FA removal under fluorescent light.

Under UV light, the decrease in $\mathrm{H}_{2} \mathrm{O}_{2}$ concentrations were $93.69,95.94$, and $59.47 \%$ for the ratio of $1: 1,1: 2$, and $1: 3$, respectively (Figure $4 \mathrm{~b}$ ). Although the amount of $\mathrm{H}_{2} \mathrm{O}_{2}$ decomposed at the ratio of $1: 2$ and $1: 3$ was close (about $1900 \mathrm{mg} / \mathrm{L}$ ), the ratio of 1:2 was more effective in COD removal. The medium with the FA: $\mathrm{H}_{2} \mathrm{O}_{2}$ ratio of $1: 2$ was found to be the optimum ratio.

It was observed that under fluorescent light, the $\mathrm{pH}$ decreased at the end of the experiment, and the highest decrease occurred at 1:1 FA: $\mathrm{H}_{2} \mathrm{O}_{2}$ sample (Table 3). As in the previous experiment, the increase in acidity can be explained by forming formic acid.

Under UV light, the initial $\mathrm{pH}$ (7.02) in all proportions studied was measured at 2.60 levels after 300 minutes. The sample's $\mathrm{pH}$ change in the ratio of 1:2 was followed during the experiment. The $\mathrm{pH}$ value was measured as 3.88 in the 10th minute. This result showed that acidic compound formation, which causes a reduction in the $\mathrm{pH}$, occurs in the first minutes of the experiment.

During the experiment at the optimum conditions, while the FA concentration decreased from 1060 to $144 \mathrm{mg} / \mathrm{L}$, the COD value decreased from 1380.92 to $522.58 \mathrm{mg} / \mathrm{L}$. The change in $\mathrm{pH}$ shows that the medium's acidification occurs in the first minutes. The COD removal was $62.12 \%$, and the reduction in FA was $86.41 \%$. The COD caused by the remaining FA ( $144 \mathrm{mg} / \mathrm{L})$ was calculated at approximately $201 \mathrm{mg} / \mathrm{L}$. This result indicates that the measured COD in the medium is due to FA and intermediates such as formic acid, and also, acidic compounds formed in the sample caused a decrease in the $\mathrm{pH}$ value. Abbaszadeh Haddad et al reported that the $\mathrm{C}-\mathrm{H}$ bond in $\mathrm{FA}$ is a relatively stronger bond than the $\mathrm{C}=\mathrm{O}$ bond. Breaking the $\mathrm{C}-\mathrm{H}$ bond is more difficult than the $\mathrm{C}=\mathrm{O}$ bond. Thus, the remaining organic content may be in the form of C-H $(27,36)$.

Temperature control was not performed in this study. During the experiment, the temperature change in the samples was followed. The studies were conducted with an initial temperature of $20^{\circ} \mathrm{C}$ and temperature changes were followed. After 300 minutes, an increase of $5-6^{\circ} \mathrm{C}$ under fluorescent light and $8-9^{\circ} \mathrm{C}$ under UV light was observed at the sample temperature. The oxidation efficiency, which decreased up to the end of the experiment, was attributed to the decreasing amount of $\mathrm{H}_{2} \mathrm{O}_{2}$ in the 
sample. There are studies conducted under temperaturecontrolled conditions and at different temperatures to investigate the effect of temperature $(37,38)$. Researchers stated that temperature change $\left(25-70^{\circ} \mathrm{C}\right)$ increased the reaction rate in the photocatalytic oxidation of oxalic acid in the first minutes but did not affect the total yield (37). Temperature changes affect chemical oxidation systems in different ways. For example, increasing temperature leads to higher reaction rates for all chemical reactions involved in heterogeneous oxidations while reducing the solubility of oxygen and ozone in an aqueous solution. Therefore, its effect on the oxidation process will vary depending on these two conditions (37).

\section{The initial concentration of FA}

To examine the effect of initial FA concentration and calculate the kinetic and isotherm parameters, different FA concentrations $(500,1000$, and $1500 \mathrm{mg} / \mathrm{L}$ ) were studied for oxidation of FA with UV light and 1000 $\mathrm{mg} / \mathrm{L} \mathrm{H}_{2} \mathrm{O}_{2}$, at original $\mathrm{pH}$. The results showed that COD removal efficiencies were $66.04,43.13$, and $10.85 \%$ for FA concentrations of 500,1000 , and $1500 \mathrm{mg} / \mathrm{L}$, respectively (Figure 5). At three FA concentrations, all $\mathrm{H}_{2} \mathrm{O}_{2}$ amounts were consumed. Maximum COD removal was obtained at $\mathrm{FA}$ concentration of $500 \mathrm{mg} / \mathrm{L}$. In the previous experiment, the optimum $\mathrm{FA}: \mathrm{H}_{2} \mathrm{O}_{2}$ ratio was found to be 1:2 (Figure 3). This experiment proved that as FA concentration increased, a decrease in the COD removal efficiency was observed. While the amount of oxidized $\mathrm{COD}$ in $\mathrm{mg} / \mathrm{L}$ was almost the same in the samples containing 500 and $1000 \mathrm{mg} / \mathrm{L} \mathrm{FA}$, this amount decreased in the sample containing $1500 \mathrm{mg} / \mathrm{L} \mathrm{FA}$. In this case, it can be concluded that increasing the organic compound amount decreases oxidation efficiency.

Similar and different studies conducted on FA removal from water and wastewater are given in Table 4.

\section{Kinetic and isotherm studies}

Pseudo-first-order, pseudo-second-order, and intraparticle diffusion model kinetic parameters were calculated to compare the kinetic models. Different initial FA concentrations (500, 1000, and $1500 \mathrm{mg} / \mathrm{L}$ ) were studied. $\mathrm{pH}$ value and $\mathrm{H}_{2} \mathrm{O}_{2}$ concentration of sample were 7.00 and $1000 \mathrm{mg} / \mathrm{L}$, respectively. COD values were measured at certain time intervals for 300 minutes.

The equations of kinetic models used were given in Eqs. (10-12).

\section{Pseudo-first-order}

$\log \left(q_{e}-q_{t}\right)=\log q_{e}-k_{1} \times t / 2.303$

where $q_{t}$ and $q_{e}$ are the oxidized amounts at a given time $t$ and equilibrium $(\mathrm{mg} / \mathrm{g})$, respectively, and $k_{1}\left(\mathrm{~min}^{-1}\right)$ is the pseudo-first-order rate constant. The parameters were calculated using the graph of $\log \left(\mathrm{q}_{\mathrm{e}}-\mathrm{q}_{\mathrm{t}}\right)$ versus $\mathrm{t}(39,40)$.

Pseudo-second-order

$\frac{t}{q}=\frac{1}{K_{2} q_{e}^{2}}+\frac{1}{q_{e}} t$

where $K_{2}\left(\mathrm{~min}^{-1}\right)$ refers to the pseudo-second-order rate constant. The parameters were calculated using the graph of $t / q_{t}$ versus $t(40,41)$.

Table 4. Similar and different studies conducted on formaldehyde removal from water and wastewater

\begin{tabular}{|c|c|c|c|c|c|c|}
\hline The method & $\begin{array}{l}\text { The initial FA or COD } \\
\text { concentration } \\
(\mathrm{mg} / \mathrm{L})\end{array}$ & $\begin{array}{l}\text { Time } \\
(\min )\end{array}$ & $\begin{array}{c}\mathrm{H}_{2} \mathrm{O}_{2} \text { and other chemicals } \\
\text { used amount }\end{array}$ & $\begin{array}{c}\text { Removal efficiency } \\
(\%)\end{array}$ & $\mathrm{pH}$ & References \\
\hline $\mathrm{UV} / \mathrm{H}_{2} \mathrm{O}_{2}$ & $1000 \mathrm{mg} / \mathrm{L}$ & 300 & $2000 \mathrm{mg} / \mathrm{L}$ & $\begin{array}{c}86.41(\mathrm{FA}) \\
62.12(\mathrm{COD})\end{array}$ & 7 & This study \\
\hline $\mathrm{UV} / \mathrm{H}_{2} \mathrm{O}_{2}$ & $400 \mathrm{mg} / \mathrm{L}$ & 100 & $\mathrm{CH}_{2} \mathrm{O}: \mathrm{H}_{2} \mathrm{O}_{2}$ ratio of $1: 2.27$ & $\begin{array}{c}99(\mathrm{DOC}) \\
100(\mathrm{FA})\end{array}$ & $6-7$ & (3) \\
\hline $\mathrm{UV} / \mathrm{H}_{2} \mathrm{O}_{2}$ & $\begin{array}{c}1200 \mathrm{mg} / \mathrm{L} \\
3000 \mathrm{mg} / \mathrm{L} \\
6000 \mathrm{mg} / \mathrm{L} \\
12000 \mathrm{mg} / \mathrm{L}\end{array}$ & 210 & $\mathrm{CH}_{2} \mathrm{O}: \mathrm{H}_{2} \mathrm{O}_{2}$ ratio of $1: 2.27$ & $\begin{array}{c}91 \\
78 \\
62 \\
21(\mathrm{DOC})\end{array}$ & $6-7$ & (3) \\
\hline $\mathrm{UV}+\mathrm{TiO}_{2}$ & $500 \mathrm{mg} / \mathrm{L}$ & 300 & - & 50 (COD) & 7 & (28) \\
\hline $\mathrm{UV}+\mathrm{ZnO}$ & $500 \mathrm{mg} / \mathrm{L}$ & 300 & - & $86(\mathrm{COD})$ & 7 & $(28)$ \\
\hline The chemical-less UVC/VUV process & $200 \mathrm{mg} / \mathrm{L}$ & 60 & - & $94(\mathrm{COD})$ & 7 & $(27)$ \\
\hline $\begin{array}{l}\text { The catalytic advanced oxidation } \\
\text { process (CAOP) of } \mathrm{O}_{3} / \mathrm{MgO} / \mathrm{H}_{2} \mathrm{O}_{2}\end{array}$ & $7000 \mathrm{mg} / \mathrm{L}$ & 120 & $\begin{array}{c}0.09 \mathrm{~mole} / \mathrm{L} \mathrm{H}_{2} \mathrm{O}_{2} \\
5 \mathrm{~g} / \mathrm{L} \mathrm{MgO} \\
0.153 \mathrm{~g} / \mathrm{L} \cdot \mathrm{min}_{3}\end{array}$ & $\begin{array}{c}79(\mathrm{FA}) \\
65.6(\mathrm{COD})\end{array}$ & 8 & $(43)$ \\
\hline $\mathrm{UV} / \mathrm{H}_{2} \mathrm{O}_{2}$ & $0.333 \mathrm{M}$ & 80 & $\begin{array}{l}0,165 \mathrm{M} \\
0.333 \mathrm{M} \\
0.666 \mathrm{M}\end{array}$ & $\begin{array}{l}34.88(\mathrm{FA}) \\
58.42(\mathrm{FA}) \\
78.80(\mathrm{FA})\end{array}$ & 2.6 & $(16)$ \\
\hline UV and ferrate(VI) & 1102 mg/L COD & 35 & - & 100 (FA) & 2 & $(47)$ \\
\hline
\end{tabular}


Table 5. Parameters of pseudo-first-order kinetic model

\begin{tabular}{lccc}
\hline $\begin{array}{l}\text { Initial Concentration } \\
(\mathbf{m g} / \mathbf{L})\end{array}$ & $\mathbf{k}_{\mathbf{1}}(\mathbf{m i n}-\mathbf{1})$ & qe $(\mathbf{m g} / \mathbf{g})$ exp. & qe (mg/g) cal. \\
\hline 500 & 0.0136 & 652.71 & 671.58 \\
\hline 1000 & 0.0124 & 479.26 & 473.15 \\
\hline 1500 & 0.00714 & 253.25 & 263.87 \\
\hline
\end{tabular}

Intra particle diffusion

$q_{t}=k_{d} t^{1 / 2}+C$

where $C(\mathrm{mg} / \mathrm{g})$ and $\mathrm{k}_{\mathrm{d}}(\mathrm{mg} / \mathrm{g} \cdot \mathrm{min})$ are the constants depending on the boundary layer thickness and the intraparticle diffusion rate constant, respectively (42).

When the parameters of three different kinetic models were evaluated, $\mathrm{R}^{2}$ values closest to 1 were obtained with pseudo-first-order kinetic model. The pseudo-firstorder kinetic curve for $500 \mathrm{mg} / \mathrm{L} \mathrm{FA}$ and parameters for three FA concentrations are given in Figure 6 and Table 5, respectively. Similar results were reported by other researchers $(16,27,3)$.

The highest removal at equilibrium was obtained at $500 \mathrm{mg} / \mathrm{L} \mathrm{FA}$ concentration. The rate constant of the COD in this study was found to be $0.0136 \mathrm{~min}^{-1}$. As the FA concentration increased, the COD removal decreased. Abbaszadeh Haddad et al reported that they found the rate constant as $0.026 \mathrm{~min}^{-1}$ with UVC/VUV process (27)

To calculate the isotherm constants, Langmuir (44) and Freundlich (45) isotherms were applied.

The equations of Langmuir and Freundlich isotherm models were given in Eqs. (13) and (14), respectively.

$\frac{C_{e}}{q_{e}}=\frac{1}{q_{\max } K_{L}}+\frac{C_{e}}{q_{\max }}$

where $q_{\max }(\mathrm{mg} / \mathrm{g})$ and $K_{L}$ are the maximum oxidation capacity and the Langmuir constant, respectively [26].

$\log q_{e}=\log K_{F}+\frac{1}{n} \log C_{e}$

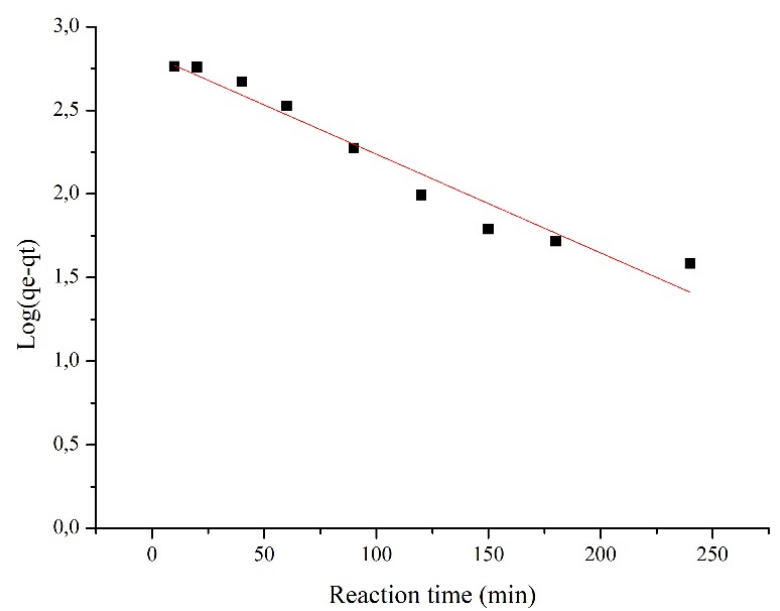

Figure 6. Pseudo-first-order chart. where $K_{F}(\mathrm{~L} / \mathrm{g})$ and $1 / n$ are the Freundlich constant and heterogeneity factor, respectively (46).

$\mathrm{R}^{2}$ values were 0.9624 and 0.9133 for Langmuir and Freundlich isotherms, respectively. The reaction was carried out according to the Langmuir isotherm model.

\section{Conclusion}

Under fluorescent light, in samples containing FA and $\mathrm{H}_{2} \mathrm{O}_{2}(1: 1)$, the highest COD removal and $\mathrm{H}_{2} \mathrm{O}_{2}$ reduction were 18.57 and $30.90 \%$, respectively, at $\mathrm{pH} 12$. In samples containing only $\mathrm{H}_{2} \mathrm{O}_{2}(500 \mathrm{mg} / \mathrm{L})$, the $\mathrm{H}_{2} \mathrm{O}_{2}$ reduction was $92.09 \%$ at $\mathrm{pH} 11.91$, while it was $2-6 \%$ at other $\mathrm{pH}$ levels. There was no change in COD caused by FA. It was observed that as $\mathrm{H}_{2} \mathrm{O}_{2}$ concentration increased, the COD removal did not increase.

Under UV light, 43-44\% COD removal was achieved in the sample containing FA and $\mathrm{H}_{2} \mathrm{O}_{2}(1: 1)$ at $\mathrm{pH} 7.02$, 9.10, and 12.24. Almost all $\mathrm{H}_{2} \mathrm{O}_{2}(1000 \mathrm{mg} / \mathrm{L})$ was consumed at each $\mathrm{pH}$ level. COD removal efficiencies at FA: $\mathrm{H}_{2} \mathrm{O}_{2}$ ratios of $1: 1,1: 2$, and $1: 3$ were $43.13,62.16$, and $53.78 \%$, respectively, at $\mathrm{pH}$ 7.02. In samples containing only $\mathrm{H}_{2} \mathrm{O}_{2}$ (1000 mg/L), the $\mathrm{H}_{2} \mathrm{O}_{2}$ concentration decreased regardless of the $\mathrm{pH}$ level.

Kinetic and isotherm studies showed that the reaction was carried out according to pseudo-first-order kinetic and Langmuir isotherm models.

For the oxidation of FA, the most effective conditions were $\mathrm{pH} 7.00$ (original $\mathrm{pH}$ ) and 1:2 of $\mathrm{FA}: \mathrm{H}_{2} \mathrm{O}_{2}$ ratio under UV light. Under these conditions, FA and COD removal were 86.41 and $62.12 \%$, respectively.

\section{Acknowledgements}

In this study, laboratory facilities in Environmental Engineering Department, Mersin University funded by Cukurova Development Agency were used (TR62/18/ ÜRET/0036). The authors would like to thank all those who supported and help them to conduct this research.

\section{Ethical issues}

All authors certify that all data obtained during the study are presented in this manuscript and no data from the study has been or will be published elsewhere separately.

\section{Competing interests}

The authors declare that they have no conflict of interests.

Authors' contributions

All authors were involved in the planning, experiments, 
and manuscript preparation of this study.

\section{References}

1. World Health Organization. Air quality guidelines for Europe. [cited 2020 Oct 20] Available from: https:// www.euro.who.int/en/publications/abstracts/air-qualityguidelines-for-europe.

2. United Nations Environment Programme, World Health Organization, International Labour Organisation. Environmental health criteria 89. [cited 2020 Oct 12] Available from: https://wedocs.unep.org/ handle/20.500.11822/29405.

3. Guimarães JR, Farah CR, Maniero MG, Fadini PS. Degradation of formaldehyde by advanced oxidation processes. J Environ Manage 2012; 107: 96-101. doi: 10.1016/j.jenvman.2012.04.024.

4. İleri TK, Çokay E, Şengül F. Toksik kirleticilerin ileri oksidasyon prosesleri ile arıtımı. Dokuz Eylül Üniversitesi Mühendislik Fakültesi Fen ve Mühendislik Dergisi 2006; 8(2): 1-9. [In Turkish].

5. Health Canada, Federal-Provincial-Territorial Committee on Drinking Water. Guidelines for Canadian Drinking Water Quality Summary Table. Canada: Health Canada; 2019.

6. World Health Organization, International Agency for Research on Cancer. IARC monographs on the evaluation of the carcinogenic risk of chemicals to humans. Lyon, France: WHO; 2010.

7. Tomkins BA, Mcmahon JM, Caldwell WM, Wilson DL. Liquid chromatographic determination of total formaldehyde in drinking water. J Assoc Off Anal Chem 1989; 72(5): 835-9.

8. Owen B, Dudney CS, Tan EL, Easterly CE. Formaldehyde in drinking water: comparative hazard evaluation and an approach to regulation. Regul Toxicol Pharmacol 1990; 11(3): 220-36. doi: 10.1016/0273-2300(90)90023-5.

9. World Health Organization, International Agency for Research on Cancer. IARC monographs on the evaluation of the carcinogenic risk of chemicals to humans, formaldehyde, 2-butoxyethanol and 1-tertbutoxypropan-2ol. Lyon, France: WHO; 2006.

10. Lu Z, Hegemann W. Anaerobic toxicity and biodegradation of formaldehyde in batch cultures. Water Res 1998; 32(1): 209-15.

11. Malakootian M, Nasiri A, Alibeigi AN, Mahdizadeh $\mathrm{H}$, Gharaghani MA. Synthesis and stabilization of $\mathrm{ZnO}$ nanoparticles on a glass plate to study the removal efficiency of acid red 18 by hybrid advanced oxidation process (ultraviolet/ZnO/ultrasonic). Desalination Water Treat 2019; 170: 325-36.

12. Alibeigi AN, Javid N, Amiri Gharaghani M, Honarmandrad Z, Parsaie F. Synthesis, characteristics, and photocatalytic activity of zinc oxide nanoparticles stabilized on the stone surface for degradation of metronidazole from aqueous solution. Environ Health Eng Manag 2021; 8(1): 55-63. doi: 10.34172/EHEM.2021.08.

13. Habibi B, Ghaderi S. Electrooxidation of formic acid and formaldehyde on the $\mathrm{Fe}_{3} \mathrm{O}_{4} @$ Pt core-shell nanoparticles/ carbon-ceramic electrode. Iran J Chem Chem Eng 2016; 35(4): 99-112. doi: 10.30492/IJCCE.2016.23592.

14. Zhang W, Song N, Guan Lx, Li F, Yao MM. Photocatalytic degradation of formaldehyde by nanostructured $\mathrm{TiO}_{2}$ composite films. J Exp Nanosci 2016; 11(3): 185-96. doi:
10.1080/17458080.2015.1043657.

15. Shie JL, Lee CH, Chiou CS, Chang CT, Chang CC, Chang CY. Photodegradation kinetics of formaldehyde using light sources of UVA, UVC and UVLED in the presence of composed silver titanium oxide photocatalyst. J Hazard Mater 2008; 155(1-2): 164-72. doi: 10.1016/j. jhazmat.2007.11.043.

16. Kajitvichyanukul P, Lu MC, Liao CH, Wirojanagud W, Koottatep T. Degradation and detoxification of formaline wastewater by advanced oxidation processes. J Hazard Mater 2006; 135(1-3): 337-43. doi: 10.1016/j.jhazmat.2005.11.071.

17. Tymoyrimoghadam L, Momeninejad $\mathrm{H}$, Baratpour $\mathrm{P}$, Gohari F, Ravansalar B, Momeninejad M, et al. Advanced oxidation of formaldehyde in the aqueous solutions using $\mathrm{UVC} / \mathrm{S}_{2} \mathrm{O}_{8}{ }^{2-}$ process: Degradation and mineralization. Environ Health Eng Manag 2019; 6(2): 97-104. doi: 10.15171/EHEM.2019.11.

18. Cheng SW, Li YH, Yuan CS, Tsai PY, Shen HZ, Hung CH. An innovative advanced oxidation technology for effective decomposition of formaldehyde by combining iron modified Nano- $\mathrm{TiO}_{2}(\mathrm{Fe} / \mathrm{TiO} 2)$ photocatalytic degradation with ozone oxidation. Aerosol Air Qual Res 2018; 18(12): 3220-33. doi: 10.4209/aaqr.2018.05.0156.

19. Deng $\mathrm{Y}, \mathrm{Zhao} \mathrm{R}$. Advanced oxidation processes (AOPs) in wastewater treatment. Curr Pollut Rep 2015; 1(3): 167-76. doi: 10.1007/s40726-015-0015-z.

20. Wang C, Bahnemann DW, Dohrman JK. Determination of photonic efficiency and quantum yield of formaldehyde formation in the presence of various $\mathrm{TiO}_{2}$ photocatalysts. Water Sci Technol 2001; 44(5): 279-86. doi: 10.2166/ wst.2001.0306.

21. Liu G, Ji J, Huang H, Xie R, Feng Q, Shu Y, et al. UV/H2O2: An efficient aqueous advanced oxidation process for VOCs removal. Chem Eng J 2017; 324: 44-50. doi: 10.1016/j. cej.2017.04.105.

22. Alpert S, Knappe DR, Ducoste JJ. Modeling the UV/ hydrogen peroxide advanced oxidation process using computational fluid dynamics. Water Res 2010; 44(6): 1797-808. doi: 10.1016/j.watres.2009.12.003.

23. Kitiş M, Yiğit NÖ, Köseoğlu H, Bekaroğlu ŞŞ. Su ve atıksu arıtımında ileri arıtma teknolojileri, arıtılmış atıksuların geri kullanımı. Ankara, Turkey: 2009.

24. Water Environment Federation. Standard methods for the examination of water and wastewater. [cited 2020 Oct 12] Available from: https://www.wef.org/resources/ publications/books/StandardMethods/.

25. Klassen NV, Marchington D, McGowan HC. H2O2 determination by the I3-method and by $\mathrm{KMnO} 4$ titration. Anal Chem 1994; 66(18): 2921-5. doi: 10.1021/ac00090a020.

26. Surpateanu M, Surpateanu GG, Zaharia C. Destruction of cyanide in aqueous solutions by oxidation with hydrogen peroxide,. Al I Cuza'Scientific Annals. Series Chem 2002; 10(1): 291-6.

27. Abbaszadeh Haddad F, Moussavi G, Moradi M. Advanced oxidation of formaldehyde in aqueous solution using the chemical-less UVC/VUV process: Kinetics and mechanism evaluation. Journal of Water Process Engineering 2019; 27: 120-5. doi: 10.1016/j.jwpe.2018.11.017.

28. Ezhilkumar P, Selvakumar KV, Jenani R, Koperun Devi N, Selvarani M, Sivakumar VM. Studies on removal of formaldehyde from industrial wastewater by photocatalytic method. Journal of Chemical and Pharmaceutical Sciences 2016; 9(1): 259-64. 
29. Czochara R, Litwinienko G, Korth HG, Ingold KU. Another unprecedented wieland mechanism confirmed: hydrogen formation from hydrogen peroxide, formaldehyde, and sodium hydroxide. Angewandte Chemie 2018; 57(29): 9186-86. doi: 10.1002/anie.201804807.

30. Lin L, Chai Y, Zhao B, Wei W, He D, He B, et al. Photocatalytic oxidation for degradation of VOCs. Open J Inorg Chem 2013; 3(1): 14-25. doi: 10.4236/ojic.2013.31003.

31. Malakootian M, Kannan K, Gharaghani MA, Dehdarirad A, Nasiri A, Shahamat YD, et al. Removal of metronidazole from wastewater by $\mathrm{Fe} /$ charcoal micro electrolysis fluidized bed reactor. J Environ Chem Eng 2019; 7(6): 103457. doi: 10.1016/j.jece.2019.103457.

32. Stefan MI, Bolton JR. Mechanism of the degradation of 1,4-dioxane in dilute aqueous solution using the UV/ Hydrogen peroxide process. Environ Sci Technol 1998; 32(11): 1588-5. doi: 10.1021/es970633m.

33. Yazıcı E, Deveci H. Factors affecting decomposition of hydrogen peroxide. Proceedings of the XIIth International Mineral Processing Symposium; 2010 Oct 6-8; Nevşehir, Turkey. doi: 10.13140/RG.2.1.1530.0648.

34. Tseng DH, Juang LC, Huang HH. Effect of oxygen and hydrogen peroxide on the photocatalytic degradation of monochlorobenzene in $\mathrm{TiO}_{2}$ Aqueous Suspension. Int J Photoenergy 2012; 2012:328526. doi: 10.1155/2012/328526.

35. Giri R, Ozaki H, Takayanagi Y, Taniguchi S, Takanami R. Efficacy of ultraviolet radiation and hydrogen peroxide oxidation to eliminate large number of pharmaceutical compounds in mixed solution. Int J Environ Sci Technol 2011; 8(1): 19-30. doi: 10.1007/BF03326192.

36. Finlayson-Pitts BJ, Pitts Jr JN. Chemistry of the Upper and Lower Atmosphere. USA: Academic Press; 1999.

37. Mehrjouei M. Advanced oxidation processes for water treatment: reactor design and case studies [dissertation]. Brandenburgischen, Germany: Brandenburgischen Technischen Universität; 2012.

38. Oppenländer T, Xu F. Temperature effects on the vacuumUV (VUV)-initiated oxidation and mineralization of organic compounds in aqueous solution using a xenon excimer flow-through photoreactor at $172 \mathrm{~nm}$. Ozone Sci Eng 2008; 30(1): 99-104. doi: 10.1080/01919510701816361.

39. Lagergren S. Zur theorie der sogenannten adsorption geloster stoffe. Kungl. Svenska Vetenskapsakad. Handl 1898; 24: 1-39.

40. Abdel-Ghani N, Rawash ES, El-Chaghaby GA. Equilibrium and kinetic study for the adsorption of p-nitrophenol from wastewater using olive cake based activated carbon. Glob J Environ Sci Manag 2016; 2(1): 11-8. doi: 10.7508/ gjesm.2016.01.002.

41. Deng S, Ma R, Yu Q, Huang J, Yu G. Enhanced removal of pentachlorophenol and 2, 4-D from aqueous solution by an aminated biosorbent. J Hazard Mater 2009; 165(1-3): 40814. doi: 10.1016/j.jhazmat.2008.10.029.

42. Saleh TA, Siddiqui MN, Al-Arfaj AA. Kinetic and intraparticle diffusion studies of carbon nanotubes-titania for desulfurization of fuels. Pet Sci Technol 2016; 34(16): 1468-74. doi: 10.1080/10916466.2016.1202972.

43. Moussavi G, Yazdanbakhsh A, Heidarizad M. The removal of formaldehyde from concentrated synthetic wastewater using $\mathrm{O}_{3} / \mathrm{MgO} / \mathrm{H}_{2} \mathrm{O}_{2}$ process integrated with the biological treatment. J Hazard Mater 2009; 171(1-3): 907-13. doi: 10.1016/j.jhazmat.2009.06.090.

44. Langmuir I. The adsorption of gases on plane surfaces of glass, mica and platinum. J Am Chem Soc 1918; 40(9): 1361-403. doi: 10.1021/ja02242a004.

45. Freundlich H. Über die adsorption in lösungen. Zeitschrift für physikalische Chemie 1907; 57(1): 385-470. doi: 10.1515/zpch-1907-5723.

46. Vijayakumar G, Tamilarasan R, Dharmendirakumar M. Adsorption, kinetic, equilibrium and thermodynamic studies on the removal of basic dye Rhodamine-B from aqueous solution by the use of natural adsorbent perlite. J Mater Environ Sci 2012; 3(1): 157-70.

47. Talaiekhozani A, Salari M, Talaei MR, Bagheri M, Eskandari Z. Formaldehyde removal from wastewater and air by using UV, ferrate(VI) and UV/ferrate(VI). J Environ Manag 2016; 184(Pt 2): 204-9. doi: 10.1016/j.jenvman.2016.09.084. 